\title{
A Solution to the Fundamental Philosophical Problem of Christology
}

\author{
Timothy Pawl \\ University of St. Thomas
}

\begin{abstract}
I consider the fundamental philosophical problem for Christology: how can one and the same person, the Second Person of the Trinity, be both God and man. For being God implies having certain attributes, perhaps immutability, or impassibility, whereas being human implies having apparently inconsistent attributes. This problem is especially vexing for the proponent of Conciliar Christology - the Christology taught in the Ecumenical Councils since those councils affirm that Christ is both mutable and immutable, both passible and impassible, etc.

Many extant solutions to this problem approach it by claiming that the predicates are incompatible when said of the same thing without qualification, but that once the appropriate qualification is added, compatibility is achieved. I provide a different approach. Here I argued that the predicates can be understood so that they are compatible. I then work out the logical relations between the predicates, so understood, showing that no contradiction follows from understanding them in the way I suggest. After that, I consider some of the motivations we have for believing the purportedly incompatible pairs to be, in fact, incompatible, and argue that, on the view offered here, we can salvage most of our intuitions that motivate taking the predicates as incompatible. Finally, I consider three objections.
\end{abstract}

\section{Introduction}

Consider the earliest seven Ecumenical Councils-the Councils held as binding by both Catholic and Orthodox Christians: The First Council of Nicaea, 325; The First Council of Constantinople, 381; The Council of Ephesus, 431; The Council of Chalcedon, 451; The Second Council of Constantinople, 553; The Third Council of Constantinople, 680-681; The Second Council of Nicaea, 787.1 Call the conjunction of the teachings about Christ from these seven councils Conciliar Christology.

Richard Cross $(2011,453)$ states the main philosophical difficulty of Conciliar Christology as follows:

${ }^{1}$ Unless otherwise noted, any quotation from an Ecumenical Council is taken from Norman Tanner's (1990) excellent 2 volume work, Decrees of the Ecumenical Councils. All inline quotations that do not list an author or year are also taken from the Tanner volumes.

Journal of Analytic Theology, Vol. 2, May 2014

10.12978/jat.2014-1.190824150011a

(C)2014 Timothy Pawl • (C) 2014 Journal of Analytic Theology 
[T]he fundamental philosophical problem specific to the doctrine is this: how is it that one and the same thing could be both divine (and thus, on the face of it, necessary, and necessarily omniscient, omnipotent, eternal, immutable, impassible, and impeccable) and human (and thus, on the face of it, have the complements of all these properties)?

Call this problem "the Fundamental Problem," or just "the Problem" for short. Others present the Problem in slightly different ways. ${ }^{2}$

There are various responses to the Problem in the theological and philosophical literature. Some, for instance, grant that the candidate pairs of predicates (e.g., "passible" and "impassible", or "mutable" and "immutable") are inconsistent, but deny that they are all had by one and the same person, the Second Person of the Trinity, the God-man Jesus Christ. Cross $(2011,464)$, for instance, does just this, "trimming" the predicates "impassible" and "immutable" from the Divine Persons. Others, for instance, Thomas Morris $(1987,67)$, deny of Christ some predicates common to all (other) humans. Still others grant that both predicates of a problematic pair are apt of Christ at some time or other, but deny that they are ever simultaneously apt of him. One type of Kenotic Christology, wherein the Word empties himself in the incarnation to such an extent that it is no longer true that he is, say, omnipotent, is one such example. ${ }^{3}$

Another family of responses makes use of the "qua" locution, consenting that were the problematic pairs apt of one and the same thing at the same time without modification, that would entail a contradiction. The "qua" moves are all attempts to modify the statement so that the pairs are not apt of the same thing at the same time in the same way. For instance, "qua" responses might modify the whole predication with a "qua" locution, ${ }^{4}$ or the subject of the predication, ${ }^{5}$ or the predicate that is said of the subject, ${ }^{6}$ or the copula which binds the subject to the predicate. ${ }^{7}$

All of these responses to the Fundamental Problem have the following assumption in common: they all assume that the problematic pairs of predicates are incompatible, if said of the same thing at the same time without modification (e.g.,

\footnotetext{
${ }^{2}$ See, for instance, Aquinas (In 3 Sent. D.6, q. 2, a. 1 obj 5), Don Cupitt $(1977,136)$, Stephen Davis $(2006,116)$, C. Stephen Evans $(2006,13)$, Michael Gorman (2000), Thomas Morris $(2009,213)$, Alan Spence $(2008,16)$, and Eleonore Stump $(2005,411-415)$ for just a few discussions.

${ }^{3}$ The history of Kenotic Christology is given in brief by Stephen Davis $(2011,114-115)$, C. Stephen Evans (2006, 3-5) and Thomas Senor $(2011,102-103)$ and in much greater depth by Thomas Thompson (2006). For expositions of Kenotic Christology, see Davis (2006; 2011), Evans (2006), Forrest (2009) and Senor (2011).

${ }^{4}$ Adams (2009, 254-255), Bäck (1998, 84-87), Cross (2005, 193-195; 2011, 455-456), Morris (1987, 48-49), and Senor $(2002,229)$ all discuss this view.

5 See Adams (2009, 255-256), Cross (2005, 195-199; 2011, 456), Leftow (2004; 2011) and Senor (2002, 229-230).

${ }^{6}$ For some discussion of this understanding of qua-clauses in relation to Christology, see Adams (2009, 253-260), Bäck (1998), Cross (2005, 204-205; 2011, 457), and Senor (2002, 230-233).

${ }^{7}$ I know of no one who discusses this option in print.
} 
"qua" modification). ${ }^{8}$ In this article, I will provide a response to the Fundamental Problem that does not share that assumption - a response that, in fact, rejects it.

In what follows I will present a way of understanding the truth conditions for the candidate pairs of (purportedly) incompatible predicates. I then work out the logic of the pairs, showing that there is no contradiction in one thing being both, say, passible and impassible, given two assumptions: (i) that the terms are understood in the way I present them, and (ii) that it is possible for one thing to have two natures. Any proponent of Conciliar Christology is bound to affirm (ii), since Conciliar Christology entails that something actually has two natures, and so it follows that it is possible for one thing to have two natures.

There seems to me to be some reason for thinking that the conciliar fathers did not view these predicates as incompatible. For, suppose that they did view these predicates as incompatible. Then surely they would not have characterized Christ in so obviously contradictory a manner as they do. For instance, the only anathema contained in the first council of the church, the Council of Nicaea, anathematizes those who say that "...the Son of God is subject to change or alteration" (5). Likewise, the conciliarly accepted letters of Cyril call the Word "unchangeable and immutable by nature" (72) and say of him that he "is unalterable and absolutely unchangeable and remains always the same as the scriptures say" (51). And yet the councils also claim that the Word suffered, died, and was buried, which requires mutability. Again, the collected fathers at the Council of Ephesus say, "we all confess that the Word of God is impassible, though in his all-wise economy of the mystery he is seen to attribute to himself the sufferings undergone by his own flesh (72-73). But the same fathers accept the creeds of the earlier councils, which include the claim that Christ - that is, the Word of God - suffered, died, and was buried.

By way of a final, and most explicit example, the fathers at the Second Council of Nicaea (Tanner 1990, 162) characterize:

One and same Christ as both invisible and visible (invisibilem et visibilem) lord, incomprehensible and comprehensible (incomprehensibilem et comprehensibilem), unlimited and limited (incircumscriptum et circumscriptum), incapable and capable of suffering (impassibilem et passibilem), inexpressible and expressible (inscriptibilem et scriptibilem) in writing. ${ }^{9}$

\footnotetext{
${ }^{8}$ To see a study of these different responses, and how they map on to responses to the Problem of Temporary Intrinsics, see my Pawl (2015)

${ }^{9}$ The Fourth Council of Constantinople (869-870AD), which is the eighth Ecumenical Council (on the Catholic reckoning of things, and so not itself part of Conciliar Christology, as I have defined it in this paper), provides this paraphrase from the Second Council of Nicaea. To see the text from Second Nicaea, see (Lamberz 2008, 3.1:254-259) For a similar text of apparently contradictory conjunctions from the Third Council of Constantinople (680-681), see (Riedinger 1990, 2:454). I thank Fr. Brian Dunkle, S.J., for helping me track down these texts.
} 
Had they really believed these five pairs of predicates to be incompatible, they would not have affirmed that Christ is both visible and invisible, incomprehensible and comprehensible, unlimited and limited, impassible and passible, and inexpressible and expressible. It is a rare feat to be able to contradict oneself so forcefully in a single sentence. Any one of these five conjunctive pairs would be enough to entail a contradiction, and the fathers do it five times over!

The conciliar fathers at the Second Council of Nicaea, between 258 and 335 bishops (Davis 1990, 308), must have all missed the obvious contradictory problem, had they understood these predicates as incompatible. And then the gathered bishops, legates and patriarchs (according to Wilhem (1908), 109 in total) who reaffirmed this teaching at the Fourth Council of Constantinople must have missed the problem as well, on the supposition that the fathers thought of these five conjunctions as being composed of incompatible predications. Attributing a failure in simple logic is uncharitable, unless we have no other rival hypothesis to explain what it is we look to explain. And attributing a massive, multigenerational egregious lapse in logical thought among hundreds of learned men (and at least one woman, Empress Irene, who summoned the Second Council of Nicaea and was present for its proceedings) is all the more uncharitable. Better, I think, to posit another explanation. One such explanation is that the predications were not meant as incompatible after all.

For all I know, the fathers might have meant the predications in a compatible manner when asserted of the same thing at the same time in the same sense, without any added qualifications. But how ought one to make sense of the predicates if they are compatible? What sort of logical havoc is such compatibility going to generate? And how do we explain our initial intuitions of the incompatibility of the candidate predicates? I turn to these three questions below.

\section{THE TRUTH CONDITIONS FOR CANDIDATE PREDICATES}

In this section I provide an initial and plausible understanding of the truth conditions for the predicates "passible" and "impassible" (section II.a.). I then provide an extended analogy (II.b.) as a means to motivating a revised understanding of the truth conditions for the predicates, which I go on to present (II.c.). Nothing of importance hangs on the particular example of problematic predicates I consider. We could just as easily have focused on one of the many other potentially problematic pairs of predicates that the Ecumenical Councils predicate of the person of Christ.

\section{II.a. Initial Truth Conditions}

Are the candidate pairs presented in the Introduction of this article incompatible? It is easy to provide intuitive truth conditions for the candidate predicates on which they are. For instance, one might understand 'passibility' and 'impassibility' as follows: 


\section{Initial Truth Conditions}

Passible:

Impassible: $\mathrm{s}$ is passible just in case it is possible that at least one other thing causally affect $s$.

$\mathrm{s}$ is impassible just in case it is not the case that it is possible that at least one other thing causally affect s. ${ }^{10}$

Given these truth conditions of the terms, it is not possible for one thing to be both passible and impassible. For, the logical form of these truth conditions is this, where "iff" means "if and only if": P iff C; IP iff $\sim$ C. Since nothing can be both possibly causally affected and not possibly causally affected, that is, nothing can be both $\mathrm{C}$ and $\sim$, nothing can fulfill the conditions required to be both P and IP.

If one is intent on keeping the predications "Christ is impassible" and "Christ is passible" true at the same time and without modification, one needs to revise the truth conditions of 'passible' and 'impassible,' and, more generally, of any candidate predicates for which one intends to employ this strategy. One desideratum when revising these truth conditions is that one be able to explain, after the revision, the reason why we thought the initial truth conditions were right. In the following sections I will offer one such revision, along with some reasoning to explain why we were prone to understand them otherwise. But first, I will offer an analogy to prime your intuitions.

\section{II.b. The Cheerleader Analogy}

Let me introduce two toy predicates for the sake of analogy.

Arm-bent:

Arm-unbent: $s$ is arm-bent just in case $s$ has an arm that is bent 90 or more degrees.

$\mathrm{s}$ is arm-unbent just in case $\mathrm{s}$ has an arm that is not bent 90 or more degrees.

One might object to using these predicates as examples by noting that, so understood, "arm-bent" and "arm-unbent" are obviously dissimilar to our initial

10 Truth conditions such as these are given, for instance, by Marcel Sarot $(1990,365)$, who says, in his study of the meaning of the term "impassible," that "the original meaning of 'impassible' is 'incapable of being acted upon by an outside force'." And Richard Creel $(2005,11)$ says, in his careful study of impassibility, as Sarot $(1990,365-366)$ points out, that "'impassibility is imperviousness to causal influence from external factors'." 
intuitions concerning "passible" and "impassible." "Passible" and "impassible" appear complementary, whereas "arm-bent" and "arm-unbent" fail complementarity twice over. Not only can something be both arm-bent and armunbent, as when a referee gives the facemasking signal during an NFL game. But also, some things are neither arm-bent nor arm-unbent, such as rocks. But if this analogy is supposed to prime our intuitions about what to think of predicates that appear to be complementary, as the predicates "passible" and "impassible" appear, this dissimilarity in appearance vitiates the analogy.

One way to gain similarity is to modify the truth conditions for being "armunbent" in light of this objection. We might take "arm-unbent" to be apt of something just in case that thing does not fulfill the conditions for being "arm-bent." That is, one way to meet this objection to the truth conditions for being "arm-unbent" is to bring the conditions in line with the standard view of complementarity.

Such a response, though, would vitiate the utility of this analogy with respect to the case of Christ. For "arm-unbent" and "arm-bent" are meant to be analogous with "impassible" and "passible." And Conciliar Christology says both "passible" and "impassible" are apt of the one person, Jesus Christ. So were we to understand "arm-unbent" and "arm-bent" such that they are incompatible, the analogy would have it that "passible" and "impassible" are incompatible, too. And this is precisely what I seek to avoid, since I am offering a response to the Problem that does not grant the incompatibility of the predicates in question.

Thankfully, modifying the definitions of our toy predicates is not the only way to gain similarity among the concepts of "arm-bent" and "arm-unbent," on the one hand, and "passible" and "impassible," on the other. Another means to gain similarity would be, not to change our understanding of the terms, but to change our understanding of the world. In what follows, I suggest a modification of our understanding of the world, only as an exercise, and not because I really believe what I'm about to suggest for the sake of analogy.

Let me introduce a fiction that will be useful in the future application of the cheerleader analogy to the case of Christ. Let me suppose that everything, rocks and all, has at least one arm. ${ }^{11}$ In such a bizarre case, at least one or the other of "armbent" and "arm-unbent" will apply to everything that exists, since everything will be such as to have an arm, and that arm will either be bent at or over 90-degrees or it will not. This answers the objector's charge of dissimilarity in part, since now one or the other of a pair of complementary predicates will apply to everything. This response does not answer the charge by denying the necessary condition the objector asserted of complementary predications - that at least one of them be predicable of each thing that exists - rather, it answers the charge by changing our understanding of reality.

To further the fiction a bit, and to consider the second half of the objection from disanalogy, suppose that our cheerleader were the only thing in existence that had more than one arm, though everything else still had a single arm. And suppose

\footnotetext{
${ }^{11}$ Arms are things; does each arm have an arm, too? Is it arms all the way down? An infinite regress of jumbled limbs? Just for the sake of illustration: yes. But see the response to the second objection below for a way of avoiding this regress.
} 
that the logicians and philosophers discussing theories of predication - unlike the fans of the cheerleader - were, as a whole, generally unconvinced of his existence, and of the need to word things in such a way that he "played well" with the theories of predication they proposed. In such a case, there might be those who understand "arm-unbent" as the objector did above: in terms of a thing's failing to have an arm bent in excess of 90-degrees. Such an understanding would be materially adequate, so far as everything besides the cheerleader is concerned. And since our imagined theorists do not believe in the cheerleader, the objector's understanding of the term would appear wholly materially adequate to them. But once we let in our radically different two-armed cheerleader, he messes up the theory.

Were there a group of individuals who believed in the cheerleader, and were they inclined to ask philosophical questions about the logical coherence of the things they believed about him, they would understand their terms differently than the cheerleader skeptics (acheerleaderists?) did. And it might not come to pass that the two groups of people would talk about their different understandings, or that they'd even be inclined to. In such a case, each truth condition for "arm-unbent" would have its own community employing it, and each community's understanding would be adequate for their purposes.

Now consider a two-armed cheerleader whose left arm is bent more than 90 degrees, but whose right arm is straight. Is it apt to say of that cheerleader "He is arm-bent"? Is it apt to say of him "He is arm-unbent"? My thought is that, given the understanding of the predicates in question, both are apt of him. The predicate, "arm-bent" is apt of him, since he has at least one arm that is such that it is bent more than 90-degrees. And so he fulfills the conditions required to say truthfully "He is arm-bent." Likewise, though, the predicate "arm-unbent" is apt of him, since he has at least one arm that is such that it is not bent more than 90-degrees. And so he fulfills the conditions required to say truthfully of him "He is arm-unbent."

Our cheerleader has two ways to fulfill the conditions required to be either arm-bent or arm-unbent. And those two ways - his two arms and their positions are independent as far as arm-bentness is concerned. If he were standing with his left arm in a position in virtue of which it is apt to say of him "He is arm-bent," and his right arm in a position in virtue of which it is apt to say of him "He is arm-unbent," we could truthfully say the following things: he is arm-bent; he is arm-unbent; he is arm-bent in virtue of (secundum; qua) his left arm; he is arm-unbent in virtue of (secundum; qua) his right arm. Furthermore, we speak wrongly when we say either of these two things: he is arm-bent in virtue of (secundum; qua) his right arm; he is arm-unbent in virtue of (secundum; qua) his left arm. For, his right arm is not a thing in virtue of which he is aptly called "arm-bent"; and likewise, his left arm is not a thing in virtue of which he is aptly called "arm-unbent."

\section{II.c. Applying the Analogy to Christ}

At this point, the analogy to Christ should be clear. What we can say of the cheerleader and his arms, we can say likewise of Christ and his natures.

In this article I will understand the natures of Christ in a concrete manner. In particular, his human nature is a concrete, particular instance of humanity. It is, 
according to the councils, a composite of body and soul. The Conciliar texts speak of the human nature assumed by Christ as "flesh enlivened by a rational soul," or a "holy body rationally ensouled," or "human flesh which is possessed by a rational and intellectual soul" (Tanner 1990, 41, 44, 115 respectively). ${ }^{12}$ On this general view of natures, a concrete nature is a particular instance of a lowest-level type. For instance, a particular instance of a certain type of dog. Everything in reality, insofar as it is a particular instance of a lowest-level type, has at least one nature. But Christ, and only Christ, has two natures.

Now consider predicates such as "invisible" and "visible." We might understand those as follows:

Visible:

Invisible: $s$ is visible just in case $s$ has a nature that is perceivable. ${ }^{13}$

$s$ is visible just in case $s$ has a nature that is not perceivable.

Now consider a two-natured person whose human nature is perceivable, but whose divine nature is unperceivable. Is it true to say of that person "He is visible"? Is it true to say of him "He is invisible"?

Given the truth conditions for the predicates, both are true of him. The predicate, "visible," is apt of him, since he has at least one nature that is such that it is perceivable. And so he fulfills the conditions required to say truthfully "He is visible." Likewise, though, the predicate, "invisible," is apt of him, since he has at least one nature that is such that it is not perceivable. And so he fulfills the conditions required to say truthfully of him "he is invisible."

Christ has two ways to fulfill the conditions required to be either visible or invisible. And those two ways - his natures and their attributes - are independent as far as visibility is concerned. He possesses the divine nature in virtue of which it is true to say of him "He is invisible," and he possesses a human nature in virtue of which it is true to say of him "He is visible." So we could truly say the following things: he is visible; he is invisible; he is visible in virtue of (secundum; qua) his human nature; he is invisible in virtue of (secundum; qua) his divine nature. Furthermore, we speak wrongly when we say either of these two things: he is visible in virtue of (secundum; qua) his divine nature; he is invisible in virtue of (secundum; $q u a$ ) his human nature. For, his divine nature is not a thing in virtue of which he is

12 The first two texts here come from the Second Letter of Cyril to Nestorius, accepted at the Council of Chalcedon. The third text comes from an anathema in the Second Council of Constantinople.

${ }^{13}$ A reader might wonder here whether the nature itself is perceivable, or whether what is perceived are the accidental features of the thing. Do we ever see the nature, or do we just see the modes or accidents or properties? To such a reader, I suggest a modification of the truth conditions for being visible. Say instead that "s is visible just in case s has a nature that, along with the other ontological components it has, is perceivable." Then whether the thing seen is the nature or the qualities inhering in the nature, or something else entirely, let whatever it is that I see when I look at you be deemed an "ontological component." 
aptly called "visible"; and likewise, his human nature is not a thing in virtue of which he is called "invisible."

Consider the two fictional assumptions I made in the cheerleader case: Everything has one arm and nothing but our cheerleader has two arms. Put in terms of natures, these assumptions are less obviously fictitious. Concerning the first, there is reason to say that every particular thing is an instance of some lowest-level type. The newly revised second assumption - that only one thing has two natures is even more plausible. While there are many two-armed things that we could point to as counterexamples to the original second assumption, we have no other twonatured things to point to as counterexamples. Furthermore, were there other twonatured things, we'd most likely say the same things about them as we say about Christ here. Scotus, for instance, does just this.

Richard Cross $(2005,200)$ quotes Scotus as saying:

This does not follow: 'this animal is blind; therefore it does not see', unless the animal has just one nature, to which one visual system belongs. For if the animal had two natures, to which two visual systems belonged, it would follow only that the animal does not see according to that nature according to which it is blind. ${ }^{14}$

I take the point to be that the following is not a valid inference form: "x is non- $F$," thus "it is not the case that $\mathrm{x}$ is $\mathrm{F}$." In cases where $\mathrm{x}$ has more than one nature, the antecedent can be true and the consequent false. For $x$ can have one nature, N1, in virtue of which "non-F" is apt of $x$ (fulfilling the antecedent), but another nature, N2, in virtue of which " $F$ " is apt of $x$ (falsifying the consequent).

The point here is that the other nature might well do the work of making it true that "Christ is P," and so it is invalid to infer from one nature making a predication of a negative true of a person ( $\mathrm{x}$ is non- $\mathrm{P}$ ), that the denial of the positive predication is true (it is not the case that $\mathrm{x}$ is $\mathrm{P}$ ). ${ }^{15}$

\section{II.d. Revised Truth Conditions}

Return to the test predicates I have been employing in this article. Rather than understanding the truth conditions for the terms "passible" and "impassible" in the initial sense, which led to difficulties in understanding the predications to be true of Christ in a non-qualified manner, we can understand them this way:

\section{Revised Truth Conditions}

Passible:

$\mathrm{s}$ is passible just in case $\mathrm{s}$ has a concrete nature that it is possible

\footnotetext{
${ }^{14}$ Cross cites Scotus, RP 3. II. 1-2, n.4 (Wadding, xi 459a).

${ }^{15}$ Similarly, Ludwig Ott says $(1960,161)$, "predication of idioms is valid in positive statements not in negative ones, as nothing may be denied to Christ which belongs to Him according to either nature."
} 
for some other thing to causally affect.

Impassible:

$\mathrm{s}$ is impassible just in case $\mathrm{s}$ has a concrete nature that it is impossible for some other thing to causally affect.

The only time that something will be able to be both passible and impassible is in the case of something having more than one nature. For, in the case of one-natured things, one can derive a contradiction from that thing being both passible and impassible, even on the revised truth conditions of the predicates.

To see the contradiction, suppose for argument's sake that some one thing, Bob, is single-natured. And also suppose that Bob is both passible and impassible in the revised senses of the terms given above. Then, by being passible, Bob has a nature that it is possible for some other thing to causally affect. Call that thing $\mathrm{x}$. Since that nature is his only nature, and since it is possible that that nature be causally affected by $\mathrm{x}$, it is false that Bob has a nature such that the nature itself is unable to be causally affected by something else. But then the righthand side of the biconditional truth condition for s's being impassible is false: Bob has no nature that it is impossible for something to causally affect. And so it is false that Bob is impassible. But we supposed that he is impassible for argument's sake. So we have derived a contradiction: Bob is impassible and it is false that Bob is impassible. Thus, our second assumption for argument must be false. And so, if something is one-natured, then it cannot be both passible and impassible in the revised sense of the terms.

\section{The Logical Relations Among the Revised Predicates}

In this section I present the truth conditions for four predicates: "passible," "impassible," "non-passible," and "non-impassible" (III.a.). I then discuss five sets of questions concerning the logical relations among the predicates (III.b.). Building on that work, I present the logical relations among the revised predicates (III.c.).

\section{III.a. The Predicates and Their Truth Conditions}

It will be useful here to provide truth conditions for the four predicates, and then show the logical interrelations between them. Consider these predicates:

$\underline{\text { Sis: }}$

Passible (P):
When:

It has a nature that is possibly causally affectable. 
Non-Passible (NP):

Impassible (I):

Non-Impassible (NI):
It is not the case that it has a nature that is possibly causally affectable.

It has a nature that it is impossible that other things causally affect.

It is not the case that it has a nature that it is impossible that other things causally affect.

It is one thing to offer stipulated truth conditions for the predicates in question that seem to avoid the difficulties at hand; it is another thing to explain the terms in a way that makes clear why they avoid the difficulties. What are the logical relations between these predicates? Can one derive a contradiction from these truth conditions, along with Conciliar Christology? I think not, as I go on to show in the next section.

\section{III.b. Question Sets}

Question Set 1: Are being non-passible and being impassible the same? Are passible and non-impassible the same? Or, aside from questions of identity, we can ask: is it true that, necessarily, something is non-passible iff it is impassible? Is it true that, necessarily, something is passible iff it is non-impassible?

Answer Set 1: "No" to all four questions. Christ, who is both P and I, given Conciliar Christology, is a counterexample to answering "Yes" to any of the four questions.

Consider the first question. Suppose that NP and I are the same. Then, since Christ is I, and since NP and I are the same, he is also NP. But, by Conciliar Christology, he is P. So something (i.e., Christ) would be aptly predicated by both complementary predicates: P and NP. And that, given the truth conditions for passible and non-passible, is impossible. Thus, NP and I are not the same.

Consider the second question. Similar reasoning shows that $\mathrm{P}$ and NI are not the same. For, suppose they are. Then, since Christ is P, he is also NI. But, by Conciliar Christology, he is I. So something (i.e., Christ) would be aptly predicated by both complementary predicates: I and NI. And that, given the truth conditions for impassible and non-impassible, is impossible. Thus, $\mathrm{P}$ and NI are not the same.

Consider the third question. Suppose that it is true that, necessarily, something is NP if and only if it is I. From that it follows that if something is I, then it is NP. But Christ is I. So Christ is NP. But again, by Conciliar Christology, Christ is P. Thus Christ is both P and NP. And that, given the truth conditions for passible and non-passible, is impossible. Thus, it is false that, necessarily, something is NP if and only if it is I.

Finally, consider the fourth question. Suppose that it is true that, necessarily, something is $\mathrm{P}$ if and only if it is NI. From that it follows that if something is $\mathrm{P}$, then it is NI. But Christ is P. So Christ is NI. But again, by Conciliar Christology, Christ is I. 
Thus Christ is both I and NI. And that, given the truth conditions for impassible and non-impassible, is impossible. Thus, it is false that, necessarily, something is $\mathrm{P}$ if and only if it is NI.

Conclusion Set 1:

C1. It is false that non-passible=impassible: $\sim(\mathrm{NP}=\mathrm{I})$.

C2. It is false that passible=non-impassible: $\sim(\mathrm{P}=\mathrm{NI})$.

C3. It is false that, necessarily, something is non-passible iff it is impassible: $\sim \square(\mathrm{NP} \leftrightarrow \mathrm{I})$.

C4. It is false that, necessarily, something is passible iff it is nonimpassible: $\sim \square(\mathrm{P} \leftrightarrow \mathrm{NI})$.

Question Set 2: Does being impassible entail being non-passible? Does being non-passible entail being impassible?

Answer Set 2: It is false that being I entails being NP, but it is true that being $\mathrm{NP}$ entails being I.

Consider the first question. It is false that being I entails being NP. For, suppose (for reductio) that being I does entail being NP. Then, as argued above, since Christ is I, he is NP. But since he is P as well, it follows that he is P and NP. And that is impossible. So it is false that being I entails being NP.

Consider the second question. Being NP does entail being I. ${ }^{16}$ To see why, suppose for reductio that it is false that being NP entails being I. If it is false that being NP entails being I, then it is possible that something is NP but not I. Call such a thing "Sally." Now, Sally either has one nature, or more than one nature. I will consider each possibility in turn in what follows.

Assume for argument that she has one nature. In such a possible situation, it is true to say, given that Sally is NP, and given the truth conditions for being NP provided above, that

S1. It is not the case that (Sally has a nature and it is possible that other things causally affect that nature).

And since, by hypothesis, Sally is not I, it is also true to say, given the truth condition of I above, that

S2. It is not the case that (Sally has a nature and it is impossible that other things causally affect that nature).

Sally, like all things, has at least one nature, though. So the first conjunct of both $\mathrm{S} 1$ and S2 is true. It is a truth of logic that if $\sim(A \& B)$ is true, and A is true, then B must be false. (For instance, if it is false that I have both an apple and a banana in my

\footnotetext{
${ }^{16}$ This argument takes as an assumption that the domain is not empty. This is a reasonable assumption, and is, in fact, entailed by most traditional forms of theism, on which God is a necessary being, and so there is no empty world. The argument also assumes that everything has at least one concrete nature.
} 
office, and I have an apple in my office, then it is false that I have a banana in my office.) And so, since both S1 and S2 are of the form (A\&B), and the first conjunct of each conjunction is true, the second conjunct of each must be false. But then it follows from $\mathrm{S} 1$ and the truth of its first conjunct that:

S3: It is not the case that it is possible that other things causally affect Sally's nature,

And from $S 2$ and the truth of its first conjunct that:

S4: It is not the case that it is impossible that other things causally affect Sally's nature.

S4, though is equivalent to S5:

S5: It is possible that other things causally affect Sally's nature.

S5 and S3 are contradictory opposites. Thus we have derived a contradiction.

The argument, put slightly differently, is as follows: If Sally has one nature and it is possible that Sally is both NP and not I, then in such a situation it would be false that it is possible that other things causally affect her nature and also false that it is impossible that other things causally affect her nature. But, that consequent is impossible. And so it is not the case that it is possible that Sally is both NP and not I, given that she has only one nature. And if it is not the case that it is possible that Sally is both NP and not I, then it is necessary that, if she is NP, then she is I. And so, given that she has only one nature, it is necessary that if she is NP, then she is I.

Similar reasoning shows that anything with more than one nature is also such that, necessarily, if it is NP, then it is I. For being NP requires having no nature that is causally affectable. And so even if something had eleven natures, none of them would be able to be causally affected, given that the thing is NP, and so each of them would be unable to be causally affected. Thus, whether something has one or more than one nature, necessarily, if it is NP then it is I.

Conclusion Set 2:

C5. Being impassible does not entail being non-passible: $\sim \square(\mathrm{I} \rightarrow \mathrm{NP})$.

C6. Being non-passible does entail being impassible: $\square(\mathrm{NP} \rightarrow \mathrm{I})$.

Question Set 3: Does being passible entail being non-impassible? Does being non-impassible entail being passible?

Answer Set 3: It is false that being P entails being NI, but it is true that being NI entails being P.

Consider the first question. It is false that being P entails being NI. For, suppose that being P does entail being NI. Then, as argued above, since Christ is P, he is NI. But since he is I as well, it follows that he is I and NI. And this is impossible. So it is false that being I entails being NP. 
Consider the second question. Being NI does entail being P. One quick way to see this entailment is as follows. Recall the above argument that being NP entails being I. Contraposed, "NP entails being I" is equivalent to "NI entails being P." But that's precisely what we seek to prove here. And so, given the success of my previous argument, the conclusion we seek to derive here follows.

Another way to show that NI entails being P is as follows. Suppose for reductio that it is false that being NI entails being $\mathrm{P}$. If it is false that being NI entails being $\mathrm{P}$, then it is possible that something is NI but not $\mathrm{P}$. Call such a thing "Reginald." Now, Reginald either has one nature, or more than one nature. I will consider each possibility in turn in what follows.

Suppose Reginald has only one nature. In such a possible situation, it is true to say, given that Reginald is NI, and given the truth condition for being NI, that

R1. It is not the case that (Reginald has a nature and it is impossible that other things causally affect that nature).

And since, by hypothesis, Reginald is not $\mathrm{P}$, given the truth condition for being $\mathrm{P}$, it is also true to say that

R2. It is not the case that (Reginald has a nature and it is possible that other things causally affect that nature).

Reginald, like all things, has a nature, though. So the first conjunct of both R1 and R2 is true. Both $\mathrm{R} 1$ and $\mathrm{R} 2$ are of the form $\sim(\mathrm{A} \& \mathrm{~B})$, and the first conjunct of each conjunction is true, so by the same truth of logic cited previously, the second conjunct of each must be false. But then it follows from R1 and the truth of its first conjunct that:

R3: It is not the case that it is impossible that other things causally affect Reginald's nature,

And it follows from R2 and the truth of its first conjunct that:

R4: It is not the case that it is possible that other things causally affect Reginald's nature.

R3, though, is equivalent to R5:

R5: It is the case that it is possible that other things causally affect Reginald's nature.

R4 and R5 are contradictory opposites. Thus we have derived a contradiction. So, given that the thing has only one nature, it follows that, necessarily, being NI does entail being $P$.

The argument, put slightly differently, is as follows: Assume Reginald has only one nature. If it is possible that Reginald is both NI and not P, then in such a 
situation it would be false both that it is possible that other things causally affect his nature and that it is impossible that other things causally affect his nature. But, that consequent is impossible. And so it is not the case that it is possible that Reginald is both NI and not P. And if it is not the case that it is possible that Reginald is both NI and not $\mathrm{P}$, then it is necessary that, if he is NI, then he is P. And so, still supposing he has only one nature, it is necessary that if he is $\mathrm{NI}$, then he is $\mathrm{P}$.

Consider the case in which Reginald has more than one nature. Again, as with Question Set 2, an increase in natures would not affect the entailment relation. For being NI requires having no nature that is causally unaffectable. And so even if something had eleven natures, none of them would be causally unaffectable, and so each of them would be able to be causally affected. Thus, whether something has one or more than one nature, necessarily, if it is NI then it is P. Thus, it is necessary that being NI entails being $\mathrm{P}$.

Conclusion Set 3:

C7. Being passible does not entail being non-impassible: $\sim \square(\mathrm{P} \rightarrow \mathrm{NI})$.

C8. Being non-impassible does entail being passible: $\square(\mathrm{NI} \rightarrow \mathrm{P})$.

Question Set 4: Can something be both non-passible and non-impassible?

Answer Set 4: No. ${ }^{17}$ Suppose, for reductio, that it is possible for something to be both NP and NI. Call that something "Darla." In such a scenario, since Darla is NP, given C6, she is also I. And since Darla is NI, given C8, she is also P. Thus, Darla is NP, NI, I, and P. This, though, is doubly contradictory. For, given their truth conditions, nothing can be both I and NI, or both P and NP. Thus, the assumption of the possibility of something being both NP and NI has entailed a contradiction, and so it is false: It is impossible for something to be both NP and NI.

\section{Conclusion Set 4:}

C9: It is not possible for something to be both NP and NI: $\sim \diamond(\mathrm{NP} \& \mathrm{NI})$.

Question Set 5: Can something be both passible and impassible?

Answer Set 5: The proponent of Conciliar Christology must answer "yes" to this question. Is there reason to think that such an answer is contradictory? I see no reason to think that something cannot be both $\mathrm{P}$ and I, given the conclusions so far. Suppose it is possible for something to be both I and P. Call that thing "Alex." Since Alex is I, he is not NI. Since he is $\mathrm{P}$, he is not NP. So Alex is I, P, $\sim \mathrm{NI}$, and $\sim$ NP.

Since he is both I and $\mathrm{P}$, the following two claims are true:

A1: Alex has a nature and it is possible that other things causally affect that nature,

And

17 This again supposes that there are no things with no concrete nature. 
A2: Alex has a nature and it is impossible that other things causally affect that nature.

Were Alex to have only one nature, then A1 and A2 would be contradictory. For, it cannot be both possible and impossible for other things to causally affect one and the same nature, at least without modifying the proposition in same way (e.g., adding temporal indices so that the nature is not both causally affectable and not causally affectable at the same time). Thus, if A1 and A2 are both true, then Alex has at least two natures.

Assuming that he has two natures, there is no inconsistency in his being both $\mathrm{P}$ and I. I have considered an argument similar in form to the previous arguments I have given (the Sally, Reginald, and Darla arguments), and shown that it does not show an inconsistency derivable from the supposition that one thing is $\mathrm{P}$ and $\mathrm{I}$. What we have derived is that anything that is both $\mathrm{P}$ and I is something with at least two natures. But this conclusion is amenable to Conciliar Christology.

Conclusion Set 5: It has yet to be derived that the following is impossible, and Conciliar Christology entails its truth:

C10: It is possible that something be both $\mathrm{P}$ and $\mathrm{I}: \diamond(\mathrm{P} \& \mathrm{I})$.

\section{III.c. The Logical Relations Presented}

What, then, are the logical relations between the four predicates: P, NP, I, and NI? It might be helpful here to borrow the traditional language and logical distinctions associated with the square of opposition. We can define the terms "complementary," "contrary," "subcontrary," and "subaltern" as follows, letting "P" and " $Q$ " stand for predicates:

Standard Logic of Predications:

$\mathrm{P}$ and $\mathrm{Q}$ are complementary:

$\mathrm{P}$ and $\mathrm{Q}$ are contraries:

$\mathrm{P}$ and $\mathrm{Q}$ are subcontraries:

$\mathrm{P}$ is subalternated to Q:
Necessarily, for any $\mathrm{x}, \mathrm{P}$ is apt of $\mathrm{x}$ just in case it is not the case that $\mathrm{Q}$ is apt of $x$.

It is possible that $\mathrm{P}$ and $\mathrm{Q}$ both are inapt of some object, but it is impossible that they are both apt of any object.

It is possible that $\mathrm{P}$ and $\mathrm{Q}$ both are apt of some object, but it is impossible that they are both inapt of any object.

Necessarily, Q entails $\mathrm{P}$, but it is false that, necessarily, P entails $\mathrm{Q}$. 
(The predicate referred to with "P" here is called the "subaltern" of the other.)

By way of example, the initial truth conditions for "passible" and "impassible" were complements; "wholly black" and "wholly white" are contraries; "non-wholly black" and "non-wholly white" are subcontraries; "mammalian" is subalternated to "human." Given these terms, we can define the relations between P, NP, I, and NI.

As is clear from the truth conditions presented at the beginning of section III.a., both P and NP, on the one hand, and I and NI, on the other, are complementary pairs.

NP and NI can both be inapt of something, according to Conciliar Christology. For, given Conciliar Christology, they are both inapt of Christ, of whom both P and I are apt. However, they cannot both be apt of something, as C9 shows. Thus, NP and NI are contraries.

I and P can both be apt of something, according to Conciliar Christology. For, given Conciliar Christology, they are both apt of Christ. However, they cannot both be inapt of something. Here's why. Suppose, for reductio, that it is possible for both $\mathrm{I}$ and $\mathrm{P}$ to be inapt of something. Call such a thing "Terrance." Then, the complements of I and P would both be apt of Terrance. So, Terrance would be both NI and NP. But C9 shows that it is impossible for something to be both NI and NP. Contradiction! Thus, it is not the case that it is possible that both I and P be inapt of something. Thus, I and P are subcontraries.

The last two logical relations to be considered are the relations between I and NP, on the one hand, and P and NI, on the other. These have been discussed above. C5 and C6 show that while NP entails I, I does not entail NP. C7 and C8 show that while NI entails P, P does not entail NI. Thus, $\mathrm{P}$ is the subaltern of $\mathrm{NI}$, and I is the subaltern of NP.

Pictorially, one can represent the relations between these predicates by borrowing the form of the Traditional Square of Opposition as follows (where the complementary relation is diagonal across the square):

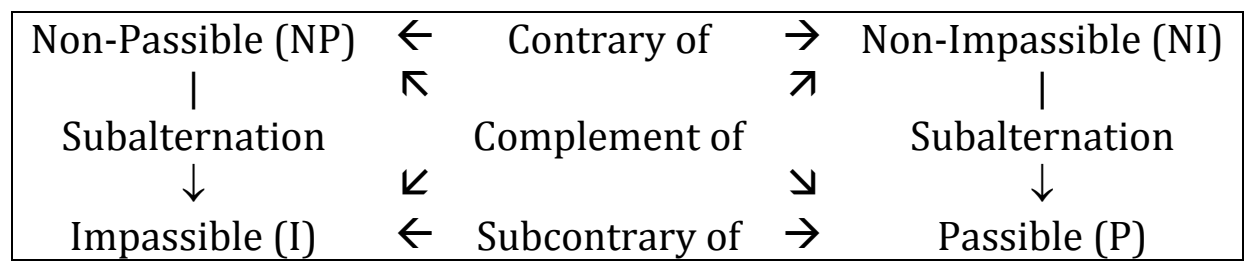

This response to the Problem, then, solves the problem by claiming the predicates to be consistent. Rather than being complementaries, or even contraries, this response claims that the candidate pairs are subcontraries. They can both be true of something, provided that (a) we understand them as they are given here (i.e., as subcontraries), and (b) that it is possible for something to have more than one nature. The latter requirement is met in our assumption of Conciliar Christology. 
Thus, if the former is consistent, which I have been at pains to show, then the proponent of Conciliar Christology has another sort of response to the Problem. ${ }^{18}$

I take myself to have presented the logic of the predicates in a clear and cogent manner. But even if the truth conditions of the terms and their logical interrelations are clear, we still have to grapple with the intuitions with which many of us began this study: that these predicates are incompatible. Is there a way to salvage some of these intuitions for the proponent of this response to the Problem? I believe that there is.

\section{EXPLAINING OUR INTUITIONS}

In this section I will discuss two intuitions we have, which might count against the understanding of the predicates that I present in section III. They are: the that intuition if " $\mathrm{x}$ is non- $\mathrm{F}$ " is true, then "it is not the case that $\mathrm{x}$ is $\mathrm{F}$ " is true (IV.a.) and the intuition that the candidate predicates are incompatible (IV.b.).

\section{IV.a. If " $\mathrm{x}$ is non-F" is true, then "it is not the case that $\mathrm{x}$ is $\mathrm{F}$ " is true}

Consider the following claim, which, intuitively, has a lot going for it:

The Claim: $\quad$ Necessarily, if " $\mathrm{x}$ is non-F" is true, then "it is not the case that $\mathrm{x}$ is $\mathrm{F}$ " is true.

The Claim seemed intuitively to be apt in the cases of candidate predicates, such as the predicates I begin this article discussing; e.g., if Christ is invisible, then it is not the case that Christ is visible. But if such predicate pairs are really subcontraries, then The Claim is false. For, given that passible and impassible are subcontraries, they can both be true of the same thing, and so there can be cases in which the

\footnotetext{
18 Robert Jenson $(2009,120)$ notes that: "When both answers to a question posed between contradictories seem wrong or both right, the question may be wrongly posed.... Perhaps, in divinis, " $x$ est passibilis" is not the right contradictory to " $x$ est impassibilis." Perhaps " $x$ non est impassibilis" with the double negative is, in divinis, the precisely right stipulation." Taking "non est impassibilis" to mean what I mean by "non-impassible," I take Jenson to be briefly gesturing toward a theory of the sort I spell out in this article. Other things he says, though, make it clear that he does not have exactly this theory in mind. For he says that neither the predicate "passible" nor the predicate "impassible" is apt of God (Jenson 2009, 120). If neither is apt of God, then the terms do not fulfill the conditions for being sub-contraries as I claim them to be.

Another person who claims incompatible predicates to be subcontraries is Charles Kelly $(1994,10)$. Unlike my argument, his reasoning proceeds from noting an alleged amphiboly in predications, his example of which is "Jesus is someone that is immortal." So far as I can tell, he retains the incompatibility of the candidate predicates, and so his response is not the same as the one offered here.
} 
antecedent is true but the consequent is false. So it is false that, necessarily, if " $\mathrm{x}$ is non- $F$ " is true, then "it is not the case that $\mathrm{x}$ is $\mathrm{F}$ " is true.

What, then, to make of The Claim and its intuitive pull? Here are two things we might do. First, we might make it explicit that The Claim only applies to complementary predicates, in which case we need not modify it, and we can still affirm its truth. Since, on the view being sketched in this article, the pairs of candidate predicates are not incompatible when said of the same thing at the same time in the same way, they are not complementary. And so, for instance, "passible" and "impassible" are not valid substitution instances for " $F$ " and "non- $F$ " in The Claim.

A second way of attempting to do justice to the intuitive pull of The Claim is to allow predicates such as "passible" and "impassible" to be valid substitution instances, but add an additional antecedent to The Claim:

The Claim*:

Necessarily, If $x$ only has one nature, then (if " $\mathrm{x}$ is non- $\mathrm{F}$ " is true, then "it is not the case that $\mathrm{x}$ is F" is true.)

The proponent of the response I offer in this article can claim that The Claim* is true. For in any case of a single-natured thing, it functions just as The Claim does. And in any case of a multi-natured thing, the whole conditional is true in virtue of having a false antecedent. Almost any intuitive pull The Claim had would be had by The Claim* as well. The proponent of this response might argue that we shouldn't expect our intuitions to be able to decide between these two principles, given the fact that our intuitions have been honed in a context where we only ever reason about one-natured things.

\section{IV.b. Intuitive Incompatibility}

What of our intuition that the relevant predicates cannot be apt of the same thing at the same time? We can agree with that assessment, in almost all cases. And it is only such cases that we consider in almost every circumstance. Again, we can salvage this intuition by claiming that the predicates, though not incompatible full stop, are incompatible given an assumption: the assumption that the thing in question has only one nature. In fact, in such a case of a thing with one nature, the predicates "passible" and "non-impassible," on the one hand, and "impassible" and "non-passible" are necessarily coextensive. And from this it follows, given the assumption that the beings in question are one-natured, that passible and impassible are complementary, as are non-passible and non-impassible. Or, put otherwise, given a domain of all and only one-natured things, C3, C4, C5, and C7 turn out to be false.

Concerning one-natured things, then, the revised truth conditions collapse back into the original truth conditions. Or, to be more precise, necessarily, for any one natured-thing, it is passible (in the original sense) if and only if it is passible (in the revised sense) if and only if it is non-impassible (in the revised sense). And 
necessarily, for any one-natured thing, it is impassible (in the original sense) if and only if it is impassible (in the revised sense) if and only if it is non-passible (in the revised sense). Knowing that the two rival views of the truth conditions of the predicates under discussion agree in all cases but the case of Christ, we might well ask ourselves whether we really are so confident that the conciliar fathers meant the terms in the original way we interpreted them. If so, whence the confidence? And if not, here we have a method of responding to the Problem.

\section{OBJECTIONS 19}

A first objection claims that my model is not very different from already proposed composite accounts of the incarnation, for instance, the accounts of Brian Leftow (2004) and Eleonore Stump (2004). ${ }^{20}$ As such, it does not move the discussion forward.

I reply: this account is different from other compositional accounts, such as Leftow's and Stump's, for no fewer than three reasons. First, their accounts suppose that the properties in question (e.g., passible and impassible) are incompatible when said in the same way of the same thing. For instance, Stump $(2004,213)$ writes that "although contradictory attributes are being predicated of the same subject, they are not being predicated in the same respect." My view, on the other hand, claims that these attributes are not contradictories, but subcontraries.

Second, Stump's quotation ends by claiming that the predicates are not predicated in the same respect. On my view, they are. Both Christ and any mundane human are passible in precisely the same respect on the theory I offer. For instance, the term, "passible," is said univocally of both you and Christ. On my view, unlike theirs, there is no need to make distinctions between how the predicate is apt of Christ (e.g., derivatively or borrowed) and how it is apt of you (e.g., non-derivatively or non-borrowed).

Third, my own view, unlike Leftow's (2004, 288-290) and Stump's (2004, 212), is not mereological in nature. ${ }^{21}$ Stump $(2004,213)$ and Leftow $(2004,288-$ 290 ) reason that at least some Candidate predications are true of Christ in virtue of a part of Christ having the very same predication true of it. I do not reason that way. I reason from natures fulfilling truth conditions (either on their own, or along with other things) to persons being characterized by predicates. Senor $(2007,64)$ charges that Stump must say that all properties of parts are borrowed by wholes to some degree or another; that, since he has an amoeba-shaped, transparent part, he too, in some way, must be amoeba-shaped and transparent. ${ }^{22}$ Leftow $(2004,290-$

${ }^{19}$ I thank an anonymous referee for voicing the need for me to raise all three of the forthcoming objections.

${ }^{20}$ For another mereological model, see Freddoso (1983).

${ }^{21}$ Both Thomas Senor (2007) and Thomas Flint (2011) attack the possibility of making such a mereological Christology work. See also Cross (2005, 196-199).

22 It is tempting to offer some response here on Stump's behalf. But I must resist due to length restraints. 
291) says that there is no good general principle to be had for when wholes borrow properties from their parts; we need, he says, to figure it out case by case. Senor (2011, 97-98) agrees that there is no good universal account to give about when properties are borrowed.

My account sidesteps these worries, since I do not reason from properties of parts to properties of wholes. I reason from truth conditions in typical contexts to truth conditions in atypical contexts. We look to whether, in a typical case, the nature, or the nature and some other thing, meets the truth conditions for a predication. If the condition is met in the typical case, then the person is aptly predicated by the predicate. Likewise, if the condition is met in the atypical case of Christ, then Christ is aptly predicated by one and the same predicate, without any modification to the predicate.

A second objection goes as follows. You claim that the predicate "impassible" should be understood as "has a nature that is unable to be causally affected." But this truth condition leads to problems. For, the conciliar texts predicate "impassible" of both the person of Christ and the divine nature of Christ. ${ }^{23}$ And while Christ does have a nature that is unable to be causally affected, his divine nature does not itself have a nature that is unable to be causally affected. Ought we to claim that concrete natures have concrete natures? That way leads to an infinite regress. In general, then, this theory requires that everything, in order to have predicates apt of it, has to have a nature, including natures. That's a lot to claim.

I reply: Here are two possible responses. First, one might revise the revised, stipulated truth conditions. Rather than "impassible" being understood as "has a nature that is unable to be affected," we might understand it as "has or is a nature that is unable to be affected."

As a second response, one might retain our previous truth condition and understand the term "has" such that $x$ has $n$ just in case $x$ is $n$, or $x$ contains $n$. This is similar to the common definition of "part," whereby a thing as a whole counts as a part of itself. Such parts - parts identical to the wholes - are called "improper parts"; similarly, we might talk about "improper having" which would refer to the first disjunct of the stipulated definition of "has" above.

In either case, whether one revises the definition itself, or whether one revises the understanding of the term "has," a nature will not need its own, distinct, nature to explain the predicates apt of it. And so the regress is avoided.

A third and final objection goes as follows. This approach seems too ad hoc; we need a sketch of how the theory is to work, more broadly construed, in order to dispel this worry.

I reply: all predicates have conditions under which they are applicable to things. These conditions sometimes require the having of something else that is a certain way (e.g., my being predicated by "arm-bent," requires my having an arm

${ }^{23}$ For instance, Cyril writes of the assembled fathers at Ephesus, "we all confess that the Word of God is impassible" (72) and the Chalcedonian fathers in their Definition of faith lament that "there are those who are trying to ruin the proclamation of the truth, and through their private heresies they have spawned novel formulas ...[some of which do so by] fantastically supposing that in the confusion [of the natures of Christ] the divine nature of the Only-begotten is passible" (84). 
that is a certain way). Other times, the predicates do not require something else being a certain way (e.g., the electron is predicated by "negatively charged" but that does not, so far as I understand it, require the electron to have something else that is a certain way). Similarly, on some traditional views, some predications require the having of something (e.g., being "sighted" requires having a power), but others require, not the having, but the privation of something (e.g., being "blind" requires the lack of the power of sight).

The fact is that the truth conditions for predicates are not uniform, and that predicates (and their truth conditions) can be stipulated into being willy-nilly. As such, we shouldn't expect a general theory of predication to be more specific than requiring predicates to meet certain conditions. Stating more informative conditions such that they apply to every predicate is hopeless.

So the question here isn't whether there is a single theory of truth conditions on offer in this solution, such that, for any predication, "s is F", it requires s to have some $\mathrm{p}$ such that $\mathrm{p}$ is $\mathrm{G}$. No theory should assert something like that. The question is: what are the conditions under which the candidate predicates (e.g., "passible" and "impassible"; "mutable" and "immutable") are apt of something, and are those conditions ad hoc? Whatever the conditions are, if Conciliar Christology is true, then they are conditions met by Christ. And so they cannot be understood in the above initial sense, wherein something meets the conditions for being "passible" just in case it fails to meet the conditions for being "impassible."

If we can find truth conditions that agree with our initial assessment of the aptness of the predicates in every mundane case, and also take into account the unique case of Christ, that would be ideal. And were we able to do so in a way that is logically respectable and fits with our intuitions, both things I have attempted to show for my suggested truth conditions, then all the better. Moreover if the theory gives us a way in which to understand the qua locutions even better yet. On this theory, the qua locutions are used to point to that which fulfills the truth conditions for the predicate in question. Since the predicates are not incompatible, this usage of the qua does not lead to inconsistency, as it does for others who attempt to understand qua in this sense. I take the solution I have offered in this paper, then, not to be ad hoc. For it does a variety of good works in addition to potentially solving the Problem. And it does them while remaining consistent with the desiderata I have listed and while providing other services (such as giving an account of qua locutions).

What I seek to supply is a way of understanding the predicates that (i) gets our pre-theoretical attributions of predicates correct, (ii) is logically consistent, and (iii) requires no revision of Conciliar Christology. The claim I have made in this article is that the understanding I have presented here does that.

\section{CONCLUSION}

In this article, I began by presenting a response to the Fundamental Problem that claims that, when properly understood, the candidate pairs are not 
incompatible with one another. This understanding requires building into predicates a clause about the subject having a nature in virtue of which something is apt of it. That whole thing, and not merely the last bit about having something apt of it, is the predicate. I then used an example of a candidate pair, "passible" and "impassible," to show the logical interrelations between the newly revised truth conditions for the predicates. After explicating the logical relations between the predicates, I moved on to discuss the intuitions one might have about predication, and I showed how to maintain those intuitions on the revised view. Finally, I asked and answered three objections to the view on offer. I conclude that I have offered a viable solution to the Fundamental Philosophical Problem of Christology that is consistent with the teachings of Conciliar Christology. ${ }^{24}$

\section{Bibliography}

Adams, Marilyn McCord. 2009. "Christ as God-Man, Metaphysically Construed." In Oxford Readings in Philosophical Theology, 239-263. Oxford University Press.

Bäck, Allan T. 1998. "Scotus on the Consistency of the Incarnation and the Trinity." Vivarium 36 (1): 83-107.

Creel, Richard E. 2005. Divine Impassibility: An Essay in Philosophical Theology. Wipf \& Stock Publishers.

Cross, Richard. 2005. The Metaphysics of the Incarnation: Thomas Aquinas to Duns Scotus. Oxford University Press.

- - - 2011. "The Incarnation." In The Oxford Handbook of Philosophical Theology, edited by Thomas P. Flint and Michael Rea, 452-475. Oxford University Press.

Cupitt, Don. 1977. “The Christ of Christendom.” In The Myth of God Incarnate, edited by John Hick, 133-147. Philadelphia: The Westminster Press.

Davis, Leo D. 1990. The First Seven Ecumenical Councils (325-787): Their History and Theology. Liturgical Press.

\footnotetext{
${ }^{24}$ I would like to thank Philip Balgeman, Oliver Crisp, Jonathan Jacobs, Samuel Newlands, Michael Rea, and Jordan Wessling for helpful discussion; Fr. Brian Daley, S.J., and Fr. Brian Dunkle, S.J., for help with the history and conciliar statements; and Matthews Grant, Ryan Mullins, Faith Glavey Pawl, Kathryn Pogin, Bradley Rettler, Michael Rota, Noel Saenz, Jeffrey Snapper, and Mark Spencer for helpful written comments on this article. Work on this article was generously supported by the Notre Dame Center for Philosophy of Religion and the John Templeton Foundation, both in the form of an Analytic Theology Summer Stipend, and in the form of a yearlong Analytic Theology Research Fellowship.
} 
Davis, Stephen T. 2006. "Is Kenosis Orthodox." In Exploring Kenotic Christology, edited by C. Stephen Evans, 112-138. Oxford University Press.

- - . 2011. "The Metaphysics of Kenosis." In The Metaphysics of the Incarnation, edited by Anna Marmodoro and Jonathan Hill, 114-133. Oxford University Press.

Evans, C. Stephen. 2006. Exploring Kenotic Christology: The Self-Emptying of God. Oxford University Press.

Flint, Thomas P. 2011. "Should Concretists Part with Mereological Models of the Incarnation?" In The Metaphysics of the Incarnation, edited by Anna Marmodoro and Jonathan Hill, 67-87. Oxford University Press.

Forrest, Peter. 2009. "The Incarnation: A Philosophical Case for Kenosis." In Oxford Readings in Philosophical Theology, edited by Michael C. Rea, 225-238. Oxford University Press.

Freddoso, Alfred. 1983. "Logic, Ontology and Ockham's Christology." The New Scholasticism 57 (3): 293-330.

Gorman, Michael. 2000. "Personal Unity and the Problem of Christ's Knowledge." Proceedings of the American Catholic Philosophical Association 74: 175-186.

Jenson, Robert. 2009. "Ipse Pater Non Est Impassibilis." In Divine Impassibility and the Mystery of Human Suffering, edited by James F. Keating and Thomas Joseph White O. P., 117-126. Wm. B. Eerdmans Publishing Company.

Kelly, Charles J. 1994. "The God of Classical Theism and the Doctrine of the Incarnation." International Journal for Philosophy of Religion 35 (1): 1-20.

Lamberz, Erich, ed. 2008. Concilium Universale Nicaenum Secundum: Concilii Actiones I-III. Vol. 3.1. Acta Conciliorum Oecumenicorum Series Secunda. Berlin: Walter de Gruyter.

Leftow, Brian. 2004. “A Timeless God Incarnate." In The Incarnation, edited by Stephen T. Davis, Daniel Kendall, and Gerald O'Collins, 273-299. Oxford University Press.

_-_. 2011. "Composition and Christology." Faith and Philosophy 28 (3): 310-322.

Morris, Thomas V. 1987. The Logic of God Incarnate. Cornell Univ Press.

- - 2009. "The Metaphysics of God Incarnate." In Oxford Readings in Philosophical Theology, edited by Michael C. Rea, 211-224. Oxford University 
Press.

Ott, Ludwig. 1960. Fundamentals of Catholic Dogma. 4th ed. Herder.

Pawl, Timothy. 2015. "Temporary Intrinsics and Christological Predication." In Oxford Studies in Philosophy of Religion, Volume 7, edited by Jonathan L Kvanvig. Oxford: Oxford University Press.

Riedinger, Rudolf, ed. 1990. Concilium Universale Constantinopolitanum Tertium. Vol. 2. Acta Conciliorum Oecumenicorum Series Secunda. Walter de Gruyter.

Sarot, Marcel. 1990. "Patripassianism, Theopaschitism and the Suffering of God. Some Historical and Systematic Considerations." Religious Studies 26 (3): $363-75$.

Senor, Thomas D. 2002. “Incarnation, Timelessness, and Leibniz's Law Problems." In God and Time: Essays on the Divine Nature. Oxford University Press.

- - - 2007. "The Compositional Account of the Incarnation." Faith and Philosophy 24 (01): 52-71.

- - . 2011. "Drawing on Many Traditions: An Ecumenical Kenotic Christology." In The Metaphysics of the Incarnation, edited by Anna Marmodoro and Jonathan Hill, 88-113. Oxford University Press.

Spence, Alan. 2008. Christology: a Guide for the Perplexed. London; New York: T \& T Clark.

Stump, Eleonore. 2004. "Aquinas's Metaphysics of the Incarnation." In The Incarnation, edited by Stephen T. Davis, Daniel Kendall, and Gerald O'Collins, 197-218. Oxford University Press.

-——. 2005. Aquinas. Routledge.

Tanner, Norman P. 1990. Decrees of the Ecumenical Councils 2 Volume Set. Georgetown University Press.

Thompson, Thomas R. 2006. "Nineteenth-Century Kenotic Christology: The Waxing, Waning, and Weighing of a Quest for a Coherent Orthodoxy." In Exploring Kenotic Christology, edited by C. Stephen Evans, 74-111. Oxford University Press.

Wilhelm, Joseph. 1908. "General Councils." The Catholic Encyclopedia. New York: Robert Appleton Company. http://www.newadvent.org/cathen/04423f.htm. 